\title{
COST-BENEFIT ANALYSIS OF PATIENTS TREATED AT A RHEUMATISM CENTRE
}

\author{
BY \\ RICHARD G. BROOKS \\ From the Department of Economics, University of Strathclyde, Glasgow, C.1
}

In recent years economists have been taking an increasing interest in the evaluation of health expenditures. One technique used has been costbenefit analysis, which attempts to evaluate as exhaustively as possible the costs and benefits of the implementation of investment projects, usually in the public sector of the economy. Cost-benefit studies have looked, for example, at cancer, tuberculosis, and poliomyelitis (Weisbrod, 1961), mental health (Fein, 1958), syphilis (Klarman, 1965), and alcoholism (Holtmann, 1963). An American study (U.S. Department of Health, Education, and Welfare, 1966) has carried out cost-benefit calculations in arthritis (covering osteoarthritis, rheumatoid arthritis, and gout). The present paper is a preliminary cost-benefit investigation in the treatment of rheumatic diseases.

\section{Material and Methods}

The analysis was based on work carried out at the Centre for Rheumatic Diseases (CRD), Glasgow. This is a self-contained 48-bed hospital under the Board of Management of the Glasgow Royal Infirmary. The study was confined to an assessment of the costs and benefits of the treatment of 366 in-patients who entered the CRD in the year April, 1965, to March, 1966.

\section{Costs}

The published cost per patient-week figure, given in the Statement of Accounts and Statistics of the Western Regional Hospital Board and Constituent Boards of Management for Year Ended 31 March, 1966, was inadequate for the purposes of cost-benefit analysis. For example, certain laboratory tests were carried out for the CRD by the Royal Infirmary, as were $x$-ray examinations. Part of the costs of these facilities had to be apportioned to the CRD. Capital costs had to be estimated and included. In addition, 119 operations were carried out on the 366 patients; since most of these operations took place at other hospitals it was necessary to cost them. All the additional cost categories are given later in Table VII.
Since out-patient costs for hospitals of the size of the CRD are not normally assessed separately from inpatient costs, an estimate was made of out-patient costs. This was then deducted from the total cost figure in order to give an in-patient cost figure which could be compared with in-patients benefits figures obtained.

\section{Benefits}

The 366 patients were arranged in five categories (see Table I). For the assessment of benefits patients were interviewed after their period of hospitalization with a view to discovering the results of treatment. For those who could be expected to be employed questions were asked of the time they lost from work before and after their in-patient stays and the dates of their returns to work (if they did). In addition, the earnings of each person were noted. For the Housewives category, questions were asked of each housewife as to her ability to do housework before and after her in-patient stay.

TABLE I

PATIENT CATEGORIES

\begin{tabular}{llr}
\hline (i) & Housewives & 159 \\
(ii) & Males (aged 18 to 65) & 78 \\
(iii) & Females (aged 18 to 65) other than housewives & 61 \\
(iv) & Old People (aged 65 years and over) & 61 \\
(v) & Young People (aged 17 years and under) & 7 \\
\hline Total & & 366 \\
\hline
\end{tabular}

It was clear that, primarily for time reasons, all these patients could not possibly be interviewed. The following procedures were therefore adopted:

(1) The Old People category was excluded from the study.

(2) A sample of patients in the Housewives category was taken. For a variety of reasons the number of housewives from which the sample was taken was reduced to 140. A random sample of 35 was chosen from this group of 140 using a random numbers table. In the event it proved possible to see only 26 of the sample of 35 patients. This was a disappointingly low figure. It is probably reasonable, however, to infer that a 
similar proportion of non-respondence would have occurred in the population of $\mathbf{1 4 0}$ housewives. Table II gives the age distribution of the Housewives sample. The majority (69 per cent.) of the sample had rheumatoid arthritis. The estimation of benefits for this category of patient was carried out on the basis of replies in interviews with the 26 patients seen.

TABLE II

AGE DISTRIBUTION: HOUSEWIVES SAMPLE

\begin{tabular}{cc}
\hline Age (yrs) & All Sample \\
\hline $25-29$ & 4 \\
$30-34$ & 3 \\
$35-39$ & 4 \\
$40-44$ & 5 \\
$45-49$ & 5 \\
$50-54$ & 3 \\
$55-59$ & 4 \\
$60-64$ & 7 \\
\hline Total & 35 \\
\hline
\end{tabular}

(3) The Males and Females categories were thought to be small enough to permit an attempt to cover as many of the patients as possible. In the event of 56 out of 75 males ( 3 males had died) and 33 of the 61 females were interviewed. Tables III and IV show the age and occupation distributions respectively of the males; 54 per cent. had rheumatoid arthritis. Tables V and VI show the age and occupation distributions of the females; again, the majority (55 per cent.) had rheumatoid arthritis.

TABLE III

AGE DISTRIBUTION: INTERVIEWED MALES

\begin{tabular}{cc}
\hline Age (yrs) & No. of Males \\
\hline Under 20 & 3 \\
$20-24$ & 3 \\
$25-29$ & 2 \\
$30-34$ & 4 \\
$35-39$ & 9 \\
$40-44$ & 9 \\
$45-49$ & 6 \\
$50-54$ & 10 \\
$55-59$ & 9 \\
$60-64$ & 1 \\
\hline Total & 56 \\
\hline
\end{tabular}

TABLE IV

OCCUPATION DISTRIBUTION: INTERVIEWED MALES

Professional (or white collar)

Skilled or semi-skilled

Self-employed

Unskilled

Unemployed

Total

29*

* It was not clear in some cases whether the patients' occupations could be regarded as semi-skilled or unskilled.

(4) The Young People category was not investigated.

\section{Assessment of Benefits}

In order to assess the benefits accruing from treatment two things were required:

(i) An acceptable benefits criterion.

(ii) A measure (or measures) of benefits. (i) Benefits Criterion.-If an employed patient was off work before entering the CRD and if this person returned

TABLE V

AGE DISTRIBUTION: INTERVIEWED FEMALES

\begin{tabular}{cc}
\hline Age (yrs) & Total Females \\
\hline Under 20 & 2 \\
$20-24$ & 2 \\
$25-29$ & 3 \\
$30-34$ & 2 \\
$35-39$ & 1 \\
$40-44$ & 1 \\
$45-49$ & 2 \\
$50-54$ & 5 \\
$55-59$ & 9 \\
$60-64$ & 6 \\
\hline Total & 33 \\
\hline
\end{tabular}

TABLE VI

OCCUPATION DISTRIBUTION: INTERVIEWED FEMALES

Clerks, secretaries, or similar

Self-employed

Nursing

Factory workers

Miscellaneous (e.g. cleaner, bus conductress)

Housekeepers

Unemployed

Total

to work at some point in time after an operation carried out during his stay in hospital and stated, on interview, that the operation was responsible for this return to work? then it was assumed that benefit had accrued. Whethere this is medically valid or whether it could be shown thaf perhaps the operation simply had a placebo effect was regarded for the purposes of this study as irrelevant.

For the Housewives category it was necessary to consider the housewife's ability to do her housework and whether this ability was improved in any way by her undergoing surgery.

(ii) Benefits Measure.-The most generally accepted measure of benefits used by economists is the earnings of a person who is able to return to work as a result of treatment. This measure was used for the Males and Females categories. The benefits calculations for Housewives were made on the basis of domestic help wages, as a rough approximation to the value of housewives' services on a replacement basis.

Perhaps undue emphasis is placed on the monetary effects of the successful treatment of patients. Are there "intangible" benefits which occur as a result of the treatment of rheumatic diseases? One such benefit is the reduction in pain that follows some types of operation or the use of drugs. Another is the lessening of a patients' physical dependence on family and friends. It is not difficult to list the intangibles, but measurement is far more problematical. A possible measure could be the reduction in expenditure on pain-killing drugs as a result of successful treatment. However, results from such a procedure are unlikely to produce reliable indications of the benefits in monetary terms of pain reduction. No attempt, therefore, was made to evaluate intangible benefits in this study. 
Procedure for Measurement of Benefits

(a) Males and Females Categories

(i) The number of successful treatment cases was determined for both categories.

(ii) The earnings figures for each successful patient were assumed to increase at real rates (that is, after allowing for inflation) of $1,2,3$, and 4 per cent. per annum.

(iii) Discount rates of 5 and 8 per cent. were applied to the earnings figures obtained at step (ii). Benefits accrue as a flow over a period of time. In order to put these benefits on a present-value basis (present-value for year April, 1965, to March, 1966) discount rates were applied to the earnings figures. The higher the discount rate, the lower the discounted present-value. The formula used was:

$$
\text { Present Value }=b_{0}+\frac{b_{1}}{1+i} \div \frac{b_{2}}{(1+i)^{2}}+\ldots+\frac{b_{n}}{(1+i)^{n}}
$$

where $b_{0}=$ benefits in year 0 (April, 1965, to March, 1966).

$b_{1}=$ benefits in year 1 (April, 1966, to March, 1967).

and so on up to $b_{n}$.

$\boldsymbol{n}=$ number of years benefits expected to accrue.

$i=$ discount rate $(i=$ either 5 or 8 per cent.).

(iv) Discounted benefits for each male were totalled in each year to give an overall benefits figure for the category for the year. The overall benefits were then aggregated over 5-year periods. The same method was applied for the female category.

\section{(b) Housewives category}

A similar method was used for the Housewives category except that:

(i) Domestic help wages paid by Glasgow Corporation during 1965-66 (approx. $£ 488$ per year) were used as the measure of benefits;

(ii) The sample results were multiplied by 4 to give estimates of benefits for the housewives population of 140 .

\section{Costs}

\section{Results}

The cost figures are summarized in Table VII. The official cost per patient-week was $£ 39$ 7s. 9d.; thus the inclusion of costs other than running costs increased total cost per patient-week by $£ 1612 \mathrm{~s} .2 \mathrm{~d}$. to $£ 5519$ s. $11 d$.
TABLE VII

BREAKDOWN OF COSTS

\begin{tabular}{lr}
\hline Hospital Running Costs & $£ 67,392$ \\
\hline Other Costs: & \\
Laboratory & 734 \\
Laboratory Test & 5,036 \\
Cardiology & 371 \\
$X$ ray & 2,235 \\
Ambulance & 1,956 \\
Operation & 9,907 \\
Consultant and Research Doctors & 3,684 \\
Capital-in-Use & 7,727 \\
\hline Total & 31,650 \\
\hline Total Costs & 99,042 \\
\hline Less Out-patient Costs & $\mathbf{3 , 2 3 1}$ \\
Total In-patient Costs & 95,811 \\
\hline Cost per In-patient Week & $£ 55$ 19s. 11d. \\
\hline
\end{tabular}

It proved necessary to make certain additional cost estimates for patients whose in-patient stays overlapped into the year April, 1966, to March, 1967 , or who made further stays in this year for additional operations. These costs amounted to $£ 4,212$. The total cost figure therefore was $£ 95,811$ $+£ 4,212$, that is $£ 100,023$.

Costs were further broken down to give figures for each patient category, in order to facilitate comparison with benefits in each patient category (see Table VIII).

TABLE VIII

COSTS: EACH PATIENT CATEGORY

\begin{tabular}{lr}
\hline Category & Total Cost \\
\hline Males & $£ 12,366(a)$ \\
Females & $£ 9,797(b)$ \\
Housewives & $£ 37,044(c)$ \\
\hline
\end{tabular}

(a) Costs for 56 males interviewed.

(b) Costs for 33 females interviewed.

(c) Estimated costs for population of 140 housewives, derived from costs of 35 sample patients multiplied by 4 .

\section{Benefits}

Males.-Benefits accrued in respect of thirteen out of the 56 patients. Of the thirteen cases, eleven had rheumatoid arthritis, one intervertebral disc degeneration, and one ankylosing spondylitis. Eleven patients had synovectomies, one had an arthrodesis, the other a laminectomy. The benefits are summarized in Table IX.

TABLE IX

BENEFITS TOTALS SUMMARY (MALES)

\begin{tabular}{|c|c|c|c|c|c|}
\hline $\begin{array}{c}\text { Discount } \\
\text { Rate }\end{array}$ & Real Earnings Growth Rate & 1 per cent. & 2 per cent. & 3 per cent. & 4 per cent. \\
\hline 5 per cent. & $\begin{array}{l}\text { 5-year total } \\
10 \text {-year total }\end{array}$ & $\begin{array}{r}70,639 \\
121,435\end{array}$ & $\begin{array}{r}72,127 \\
126,614\end{array}$ & $\begin{array}{r}73,515 \\
131,807 \\
\end{array}$ & $\begin{array}{r}75,655 \\
138,709 \\
\end{array}$ \\
\hline 8 per cent. & $\begin{array}{l}5 \text {-year total } \\
10 \text {-year total }\end{array}$ & $\begin{array}{r}65,882 \\
106,907\end{array}$ & $\begin{array}{r}67,448 \\
111,604\end{array}$ & $\begin{array}{r}69,003 \\
116,475\end{array}$ & $\begin{array}{r}70,627 \\
121,676\end{array}$ \\
\hline
\end{tabular}

Calculations for periods beyond the 10-year total were carried out. 
COMPARISON OF BENEFITS WITH COSTS (MALES)

Costs for the Males category were $£ 12,366$ (Table VIII). Table IX shows that, under all assumptions of real earnings, and growth rates and with either discount rate used, benefits exceed costs. Even under the most pessimistic assumptions, that all the patients will have ceased work by the end of 5 years, that real earnings will increase by 1 per cent. per annum, and using the higher discount rate, benefits $(£ 65,882)$ exceed costs $(£ 12,366)$ by $£ 53,516$.

Females.-The cost figure for the Females category was $£ 9,797$ (see Table VIII). Benefits for this category are summarized in Table $X$. Benefits accrued to six out of 33 patients, three with rheumatoid arthritis, one polyarthritis, one systemic lupus erythematosus, and one intervertebral disc degeneration). There were three synovectomies, one patellectomy, one laminectomy, and one knee exploration (this appeared to be a "placebo effect" case).

COMPARISON OF BENEFITS WITH COSTS (FEMALES)

Table $X$ shows that the lowest benefits figure is $£ 18,021$, which is greater than costs $(£ 9,797)$ for this category.

Housewives. - Costs for the Housewives category amounted to $£ 37,544$ (see Table VIII). Benefits for this category are summarized in Table XI. The three sample patients concerned (the successful cases) all suffered from rheumatoid arthritis and all had synovectomies.
COMPARISON OF BENEFITS WITH COSTS (HOUSEWIVES)

For this category costs exceed benefits at the most $\overline{3}$ pessimistic cut-off date-costs $(£ 37,544)$ exceed the highest benefits figure $(£ 26,953$, see Table XI $(i i))$ at the 5-year date. At the 10-year date benefits exceed costs under all different assumptions.

\section{Overall Comparison of Benefits with Costs}

The overall cost for in-patients amounted to $£ 100,023$ (see Costs Section). This was the cost of keeping all 366 patients in the CRD.

Table XII (opposite) shows that the benefits figure by the most pessimistic assumptions -8 per cent. discount rate, 5-year cut-off date, 1 per cent. real $\omega$ earnings growth rate-was $£ 106,672$. The net present value rule for investment decisions is that projects which have a positive net present value ${\underset{\infty}{N}}_{\infty}$ (present value of benefits is greater than present $\sigma$ value of costs) should be undertaken. Since of $£ 106,672$ is the present value of benefits and $£ 100,023 \mathrm{G}$ is the present value of costs, this means that net $\frac{\text { 의 }}{2}$ present value amounted to $£ 6,649$.

\section{Discussion}

The result of the study was that benefits exceeded $\frac{1}{3}$ costs under all assumptions used in the calculation $\stackrel{\mathbb{Q}}{-}$ of benefits. This represents at least a prima faci $\overrightarrow{0}$ case for investing resources in institutions like the 8 Centre for Rheumatic Diseases. It will be realize however, that the results presented here do not give

TABLE X

BENEFITS TOTALS SUMMARY (FEMALES)

\begin{tabular}{|c|c|c|c|c|c|}
\hline $\begin{array}{l}\text { Discount } \\
\text { Rate }\end{array}$ & Real Earnings Growth Rate & 1 per cent. & 2 per cent. & 3 per cent. & 4 per cent. \\
\hline 5 per cent. & $\begin{array}{l}5 \text {-year total } \\
10 \text {-year total }\end{array}$ & $\begin{array}{l}19,189 \\
33,679\end{array}$ & $\begin{array}{l}19,623 \\
35,214\end{array}$ & $\begin{array}{l}20,073 \\
36,851\end{array}$ & $\begin{array}{l}20,528 \\
38,562\end{array}$ \\
\hline 8 per cent. & $\begin{array}{l}\text { 5-year total } \\
\text { 10-year total }\end{array}$ & $\begin{array}{l}18,021 \\
24,875\end{array}$ & $\begin{array}{l}18,414 \\
31,061\end{array}$ & $\begin{array}{l}18,822 \\
32,419\end{array}$ & $\begin{array}{l}19,239 \\
33,853\end{array}$ \\
\hline
\end{tabular}

Calculations for periods beyond the 10-year total were carried out.

TABLE XI

BENEFITS TOTALS SUMMARY: HOUSEWIVES

\begin{tabular}{|c|c|c|c|c|c|c|}
\hline Summary & $\begin{array}{l}\text { Discount } \\
\text { Rate }\end{array}$ & Replacement Cost Growth Rate & 1 per cent. & 2 per cent. & 3 per cent. & 4 per cent. \\
\hline \multirow{2}{*}{$\stackrel{(i)}{\text { Sample }}$} & 5 per cent. & $\begin{array}{l}5 \text {-year total } \\
10 \text { year total }\end{array}$ & $\begin{array}{r}6,177 \\
11,550\end{array}$ & $\begin{array}{r}6,358 \\
12,167\end{array}$ & $\begin{array}{r}6,547 \\
12,828\end{array}$ & $\begin{array}{r}6,738 \\
13,520\end{array}$ \\
\hline & 8 per cent. & $\begin{array}{l}5 \text {-year total } \\
10 \text {-year total }\end{array}$ & $\begin{array}{l}5,692 \\
9,995\end{array}$ & $\begin{array}{r}5,855 \\
10,503\end{array}$ & $\begin{array}{r}6,024 \\
11,045\end{array}$ & $\begin{array}{r}6,198 \\
11,619\end{array}$ \\
\hline \multirow{2}{*}{$\underset{\substack{\text { Sample } \\
\text { Multiplied } \\
\text { by }}}{(i i)}$} & 5 per cent. & $\begin{array}{r}5 \text {-year total } \\
10 \text {-year total }\end{array}$ & $\begin{array}{l}24,708 \\
46,199\end{array}$ & $\begin{array}{l}25,433 \\
48,666\end{array}$ & $\begin{array}{l}26,187 \\
51,311 \\
\end{array}$ & $\begin{array}{l}26,953 \\
54,082\end{array}$ \\
\hline & 8 per cent. & $\begin{array}{l}5 \text {-year total } \\
10 \text {-year total }\end{array}$ & $\begin{array}{l}22,770 \\
39,979\end{array}$ & $\begin{array}{l}23,421 \\
42,010\end{array}$ & $\begin{array}{l}24,096 \\
44,180\end{array}$ & $\begin{array}{l}24,790 \\
46,478\end{array}$ \\
\hline
\end{tabular}

* Slight discrepancies occur in the figures due to rounding off.

Calculations for periods beyond the 10-year total were carried out. 
TABLE XII

BENEFITS TOTALS SUMMARY: ALL CATEGORIES*

\begin{tabular}{|c|c|c|c|c|c|}
\hline $\begin{array}{l}\text { Discount } \\
\text { Rate }\end{array}$ & Real Earnings Growth Rate & 1 per cent. & 2 per cent. & 3 per cent. & 4 per cent. \\
\hline 5 per cent. & $\begin{array}{l}5 \text {-year total } \\
10 \text {-year total }\end{array}$ & $\begin{array}{l}114,536 \\
201,313\end{array}$ & $\begin{array}{l}117,183 \\
210,494\end{array}$ & $\begin{array}{l}119,775 \\
219,969\end{array}$ & $\begin{array}{l}123,136 \\
231,353\end{array}$ \\
\hline 8 per cent. & $\begin{array}{l}5 \text {-year total } \\
10 \text {-year total }\end{array}$ & $\begin{array}{l}106,675 \\
176,671\end{array}$ & $\begin{array}{l}109,283 \\
184,675\end{array}$ & $\begin{array}{l}111,921 \\
193,074\end{array}$ & $\begin{array}{l}114,656 \\
202,007\end{array}$ \\
\hline
\end{tabular}

* Benefits totalled from Tables IX, X, and XI (ii).

unqualified justification for this particular investment decision. In particular it may be just as worthwhile (similar net present values) to incorporate such facilities for the treatment of rheumatic diseases into a general hospital, or it may be more worthwhile (greater net present values). Clearly work would be required on the sort of costs, bed turnover, time lags between operations, and so on, which occur in general hospitals - that is, more cost-benefit-type studies-before any conclusions about the allocation of resources could be drawn.

Some of the drawbacks associated with cost-benefit analysis in the present study will now be noted. In the first place, it is extremely difficult to take into account all the costs and benefits of treating and rehabilitating patients. In this study intangible benefits were virtually ign .. red; the benefits of research were not mentio .e:: the benefits figures given may be biased upvar: $\therefore$ or downwards by a multiplicity of other factors (housing, conditions of work, diet, etc.); costs of returning patients to work may be underestimated by not taking into account such factors as the costs of physiotherapy and other treatment at other hospitals and clinics; drugs and their effects on health and employment were not considered. In principle, most of these deficiencies can be overcome by careful statistical analysis. One further point regarding statistics is that the numbers taken for analysis in this particular study are extremely small and therefore one would hesitate to place great significance on the results given.

One of the most important drawbacks to the study of health expenditures in a cost-benefit manner is the problem of the multiplicity of variables. Precisely what effect does a particular health programme or set of health facilities have on the health of a population? Economists are agreed that much more work must be done on this particular problem before the precise influence of health expenditure will become apparent. The present study is no exception to the general rule, that variables other than health may have distorted the figures given.

Discussion about the choice of the benefits criterion is undoubtedly required. The decision to use the successful operations criterion was taken on the grounds that synovectomy seemed to be proving medically successful in the sense of relieving joint pain. Synovectomy follow-up studies are in process which may confirm this. Since 74 out of 119 operations carried out on the 366 CRD patients studied were synovectomies, it appeared worthwhile to interview patients with a view to discovering whether these operations had returned them to work or to housework. In those cases regarded as "successful" in this study, synovectomies (or other types of operation) were given as the reason for return to work. On this rather narrow, if subjective, criterion, very few patients among those actually interviewed were success cases (22 out of 115 patients interviewed, thirty of whom were operated on). Nevertheless, benefits exceeded costs and it is clear that, if synovectomy, for example, is the instrumental factor in enabling patients to return to work, then considerable economic benefits ensue. However, virtually no mention so far has been made of other forms of treatment, such as drugs.

Can the administration of drugs enable a return to work? In individual patient cases this may be so. However, the measurement of the effectiveness of drugs has problems associated with it. For example, it was found from interviewing patients in this study that many of them had either had the dosage of particular drugs changed or the type of drug changed over a period of time. This made it difficult to assess the help a person was obtaining from the use of drugs. Clearly problems of this type have to be surmounted by the construction and implementation of medical trials. The economic effectiveness of such trials may well be a subject for future study. It was decided in the current study not to attempt measurement of the benefits accruing from drug treatment.

The possibility of looking from an economic point of view at the results of medical trials, at the success or otherwise of different types of operation, at the effectiveness of such methods of treatment as physiotherapy, leads to more positive conclusions to be drawn about cost-benefit analysis, or at any rate, economic analysis in the field of expenditure on rheumatic diseases. Whatever may be said about 
the tendency of economists to concentrate solely on the economic effects of health treatment, to the exclusion of (perhaps more important) non-economic effects, it should be realized that important resource allocation decisions have to be made in the health expenditure field as with any other form of expenditure. If the economist can show the different economic effects of different types of treatment and different types of facilities, both within the rheumatic diseases field and within the health sector generally, then health administrators and medical personnel will have more information on which to base the decisions they have to take. Consequently it is hoped that methods of decision-taking will improve. Cost-benefit analysis is one of the ways in which economists can help to provide the required information. This paper has aimed at giving an indication of the possibilities for this type of analysis in the field of rheumatic diseases.

\section{Summary}

(1) A preliminary attempt has been made to assess the costs and benefits of the treatment of rheumatic diseases, based on an analysis of the in-patients treated at the Centre for Rheumatic Diseases, Glasgow, in the year April, 1965, to March, 1966.

(2) 56 out of 75 males (aged 18-65), 33 out of 61 females (aged 18-65, other than housewives), and 26 out of a sample of 35 housewives (159 housewives entered as in-patients) were interviewed.

(3) Running costs were taken from the Statement of Accounts and Statistics of the Western Regional Hospital Board for Year Ended March 31, 1966, and additional estimates were made for a number of other cost categories, including for example capital costs and ambulance costs, which did not appear in the running costs figure. Overall costs amounted to $£ 100,023$.

(4) The benefits criterion used was return to work as a result of operation (Males and Females categories), or regained ability to do housework (Housewives category). The measure of benefits used was earnings (Males and Females), or domestic help replacement cost (Housewives). By applying real is earnings growth rates to the earnings figures, and then discounting these figures at 5 per cent. and 8 per cent. to allow for the fact that benefits accrue as flows over time, discounted benefits figures were obtained. Various cut-off dates were then applied to these aggregated benefits figures.

(5) Benefits were compared with costs for each category of patient and overall benefits were then $\delta$ compared with overall costs. It was shown that $\mathrm{F}$ net present value was positive (present value of benefits exceeded present value of costs) under all the assumptions used to calculate the benefits figures.

(6) The conclusion drawn was that there was a prima facie economics case for investing resources into the treatment of rheumatic diseases. The qualifications to this conclusion were discussed.

The author was in receipt of a Social Science Researct Council Grant at the time this study took place. He gratefully acknowledges the considerable help given by Dr. W. W. Buchanan and the medical staff, and by Miss E. McQuade and the nursing and administrative staff, $\mathbb{D}$ of the Centre for Rheumatic Diseases. He also wishes to thank all the patients who willingly agreed to be interviewed.

\section{REFERENCES}

Fein, R. (1958). "Economics of Mental Illness." Basic Books, New York.

Holtmann, A. G. (1964). Public Finance (The Hague), 19, 351 (Estimating the demand for public health services: The alcoholism case).

Klarman, H. E. (1965). "Syphilis control programs," in "Measuring Benefits of Government Investments: Papers presented at a Conference of Experts, 1963," ed. R. Dorfman, p. 367. The Brookings Institution, Washington, D.C.

U.S. Department of Health, Education, and Welfare (1966). "Program Analysis 1966-4. Disease Control Programs: Arthritis."

Weisbrod, B. A. (1961). "Economics of Public Health." University of Pennsylvania Press, Philadelphia.

L'analyse des frais de traitement à un centre rhumatismal et l'évaluation monétaire des bénéfices de ce traitement

\section{RÉSUMÉ}

(1) Une tentative préliminaire a été faite pour évaluer le coût du traitement des malades rhumatismaux et ses bénéfices pratiques, se basant sur une analyse des malades admis et traités au centre des maladies rhumatismales à
Anàlisis del costo-beneficio de pacientes tratados en un centro de reumatismo

\section{Sumario}

(1) Se ha realizado una tentativa preliminar para evaluar los costos y beneficios del tratamiento de enfermedades reumáticas, basada en un análisis de los pacientes internos atendidos en el Centro de Enfermedades 
Glasgow pendant les douze mois entre avril 1965 et mars 1966.

(2) 58 des 75 hommes (âgés de 18 à 65 ans), 33 des 61 femmes (âgées de 18 à 65 ans, autres que des ménagères), et 26 d'un groupe de 35 ménagères (159 ménagères considérées comme malades admises) ont été questionnés.

(3) Les dépenses courantes ont été prises du Statement of Accounts and Statistics of the Western Regional Hospital Board pour l'année échue le 31 mars 1966, et des prévisions supplémentaires ont été faites pour un certain nombre d'autres catégories de dépenses telles que les dépenses en immobilisations et le coût des ambulances qui ne paraissaient pas dans le chiffre des dépenses. Le coût total se montait à $£ 100,023$.

(4) Le critère des allocations employé était le retour au travail après l'opération (catégorie hommes et femmes) ou le fait de pouvoir faire de nouveau le travail de la maison (catégorie des femmes menagères). La mesure des bénéfices employée était les gages (hommes et femmes) ou le coût du remplacement des ménagères par des assistantes domestiques. On a tenu compte du mouvement général, avec le passage du temps, des gages et des prix.

(5) Les bénéfices ont été compareés aux depenses pour chaque categorie de malades et le total des bénéfices a alors été comparé aux dépenses totales. Il a été démontré que la valeur réelle nette était positive (la valeur réelle des benéfices excédait la valeur réelle des dépenses).

(6) La conclusion faite était qu'il y avait, à première vue, une raison économique pour l'investissement de fonds pour le traitement des maladies rhumatismales. Les réserves attachées à cette conclusion ont été discutées.
Reumáticas, de Glasgow, en el año transcurrido entre abril de 1965 y marzo de 1966.

(2) Fueron interrogados 58 de 75 hombres (de entre 18 y 65 años), 33 de 61 mujeres (de entre 18 y 65 años, que no eran amas de casa), y 26 de un grupo representativo de 35 amas de casa (159 amas de casa registradas como pacientes internos).

(3) Los gastos fueron obtenidos del Estado de Cuentas y Estadisticas de la Junta Hospitalaria Regional Occidental, del Año que Terminó el 31 de Marzo, 1966, y se hicieron cálculos adicionales para varias otras categorias de gastos, que abarcaban por ejemplo costos de capital y costos de ambulancia, que no estaban incluidos en la cifra de costos. Los costos generales se elevaban a £100.023.

(4) El criterio usado en cuanto a beneficios fue el retorno al trabajo como resultado de una operación (en la categoría de hombres y mujeres), o recuperación de la aptitud para realizar tareas caseras (en la categoría de amas de casa). La medida de los beneficios, usada en estos casos, fue: rentas (hombres y mujeres) o costo de ayuda doméstica (amas de casa). Aplicando promedios de aumento de salarios actuales a las cifras de rentas (ingresos) y luego descontando estas cifras al 5 y 8 por ciento para compensar el aumento que experimentan los beneficios acumulados a lo largo de determinado periodo. se obtuvieron cifras de beneficios descontadas. Estos beneficios agregados fueron calculados en varios periodos de enfermedad.

(5) Los beneficios fueron comparados con los costos en cada categoría de pacientes, y los beneficios totales fueron, entonces, comparados con los costos totales. Se demostró que el valor actual neto era positivo (el valor actual de los beneficios excedía el valor actual de los costos) en todas las circunstancias imaginadas para calcular las cifras de beneficios.

(6) Se llegó a la conclusión de que existía un caso de economía prima facie, que justificaba la inversión de recursos destinados al tratamiento de las enfermedades reumáticas. Se discutieron los elementos que habilitaban esta conclusión. 